\title{
PRIVATIZING HighWAYS IN THE UNITED STATES
}

\section{Eduardo Engel, Ronald Fischer And AleXander Galetovic ${ }^{1}$}

First Version: June, 2005.

This Version: August, 2005.

\begin{abstract}
Major increases in congestion over the last two decades, combined with troubled government finances, have made private toll-roads increasingly attractive in the United States. Road privatization consists in having a private firm build, operate and maintain the road for many decades. The main (often only) source of income for the franchise holder is toll revenue.

We review the experience of both private toll-roads built in the United States during the 1990s, and argue that the problems they encountered could have been avoided if the length of the franchise contract had adapted to demand realizations. We also argue in favor of adjudicating private toll-roads in competitive (Demsetz) auctions. Both advantages are attained if the highway is auctioned to the firm that bids the least present value of toll revenue (PVR), an approach we discuss in detail throughout the paper.
\end{abstract}

\footnotetext{
${ }^{1}$ We gratefully acknowledge comments and suggestions from James Hines, Stephane Saussier and participants at the "Privatization: Issues of State and Local Public Infrastructure" Conference organized by University of Michigan's Office of Tax Policy Research (OTPR) and Center for Local, State and Urban Policy (CLOSUP) and the "Public-Private Partnerships: Theoretical Issues and Empirical Evidence" International Conference organized by the ADIS Center, University of Paris 11 - Sceaux.

Engel: Department of Economics, Yale University, 28 Hillhouse Ave., New Haven, CT 06511, USA. Fischer: Center for Applied Economics (CEA), Department of Industrial Engineering, University of Chile, Av. República 701, Santiago, Chile. Galetovic: Facultad de Ciencias Económicas y Empresariales, Universidad de Los Andes, San Carlos de Apoquindo 2200, Santiago, Chile.

E-mails: eduardo.engel@yale.edu, rfischer@di.uchile.cl, agaletovic@uandes.cl.
} 


\section{INTRODUCTION}

Highway demand has grown well ahead of capacity in the United States over the last two decades, leading to major increases in congestion. For example, urban interstate miles at over $71 \%$ capacity in peak periods-a common indicator of congestion-grew steadily from $31 \%$ in 1980 to 55\% in 1994, while the same measure for other freeway miles doubled from 20 to $40 \%$ over the same period. ${ }^{2}$ Also, congestion costs in the top U.S. metro areas have grown steadily, reaching $\$ 63.1$ billion in $2003,60 \%$ higher (in real terms) than a decade earlier (see Schrank and Lomax, 2005).

Figure 1 depicts the evolution of spending for highways in the United States from 1985 onwards. It shows that states and local governments have increased their spending by approximately $50 \%$. By contrast, federal spending remained relatively constant until 1998, when the Transportation Equity Act for the 21st Century (TEA-21) was passed, which led to an increase of 25\% in federal spending between 1998 and 2003, compared with 1992-1997. ${ }^{3}$ A similar pattern—constant federal spending between 1985 and 1998 and a significant increase in federal spending during the same period-emerges if we consider highway spending as a fraction of total government spending, as illustrated by Figure 2 for the case of federal spending. This figure considers a longer time period (1956-1998), showing that the long run trend has been toward a lower fraction of federal expenditures on highways.

The Federal-Aid Highway Act of 1956 played a central role financing highways in the U.S. during the last 50 years, including over 46,000 miles of the Interstate Highway System. ${ }^{4}$ This act established the Highway Trust Fund (HTF), financed mainly with fuel taxes. ${ }^{5}$ Beginning in the 1980s, an increasing fraction of the fund was spent on transport projects unrelated to highways, suggesting that major additional federal resources, far beyond TEA-21, were necessary to catch up with highway demand. Such resources are unlikely to be available any time soon given current (and projected future) deficits.

It is clear then that increased congestion, combined with a trend toward lower taxes and smaller government, have made private toll-roads an increasingly attractive option for state and local authorities that need to increase their investment in highways, since new highways can be built in this way without resorting to scarce government budgets. ${ }^{6}$ It is therefore remarkable that very few private toll-roads have been built in the United States during the last two decades. The most important ones are the Dulles Greenway in Virginia

\footnotetext{
${ }^{2}$ See Figure 2 in Winston (2000). A change of methodology in the compilation of congestion measures beginning in 1995 makes it difficult to compare congestion in 1995 and years thereafter with that in previous years.

${ }^{3}$ After expiring on September 30, 2003, TEA-21 was extended several times while Congress worked on its Reauthorization. On April 2, 2005, the House passed a version of the long delayed legislation that calls for $\$ 283.9$ billion over six years. On May 17 the Senate approved its version of the bill, by a resounding $89-11$ vote, calling for $\$ 295.1$ billion. The $\$ 11.2$ billion difference is not a minor issue, since the Bush administration has threatened a veto if the final version tops the amount in the House version.

${ }^{4}$ Even though this accounts for only $1 \%$ of U.S. road mileage, it accounts for $24 \%$ of all vehicle-miles. See Roth (2003).

${ }^{5}$ In 1995, federal motor fuel taxes provided $\$ 15.7$ billion for the HTF. Other sources of revenue came from excise taxes on tires, trucks, buses, and trailers $(\$ 2.4$ billion). The heavy-vehicle use tax, which is imposed annually on vehicles whose gross weights exceed 55,000 pounds, raised $\$ 682$ million for the HTF.

6 "Viewing private participation as a source of badly needed capital, officials in some states have welcome private investment in toll-roads." Congressional Budget Office (1998, p. xii). Also: "Tolls [...] represent an ideal way for financing both new highway capacity and maintaining the current stock." Adams et al. (2001).
} 
and the 91 Express Lanes in Orange County, California. ${ }^{7}$ Other major private toll-roads we are aware of are the Chicago Skyway (operational 2005) and San Diego's SR 125 (currently under construction). ${ }^{8}$

Even though slowly, interest in private toll-roads is increasing steadily across the United States. More than 20 states have passed legislation in recent years allowing the operation of private toll-roads, often letting the private sector build and operate these roads. ${ }^{9}$ This shift toward private toll-roads was recently justified by Delaware's Secretary of Transportation on the ground that "we have so many projects and so little money." 10

It is likely, then, that we will see a surge in private toll-roads during coming years. In this paper we argue that whether such a trend will be successful depends on avoiding the pitfalls encountered in the few private toll-roads put in place during the 1990s.

Private toll-roads often run into serious problems because of fundamental contract design flaws that originate from the combination of high demand uncertainty and incompleteness that characterizes these contracts (Engel, Fischer and Galetovic, 1996, 1997b). In this paper we discuss the relevance of our previous work on private toll-roads for the United States. We argue that the two most important private toll-roads built in the United States during the 1990s ran into serious problems because of poor contract design. These problems could have been avoided if flexible term franchises, such as the Present-Value-of-Revenue franchises we have advocated elsewhere (Engel, Fischer and Galetovic, 1996, 2001), had been used.

Motivated by the recent U.S. experience with private toll-roads, we address two conceptual questions in this paper. First, when should private toll-roads be preferred over government provision? Second, what is the optimal contract in those cases where private toll-roads are more desirable? We also consider a number of practical issues that arise when designing highway franchise contracts.

The remainder of the paper is organized as follows. Section 2 compares private toll-roads with the traditional approach to highway provision. Section 3 describes in detail the U.S. experience with private toll-roads during the 1990s. Section 4 presents a simple framework that formalizes some of the issues discussed in Sections 2 and 3. Section 5 discusses implementation and contract design issues for private toll-road contracts and compares PVR contracts with their fixed term counterparts in more detail. Section 6 concludes.

\section{Comparing the Traditional and Private Approaches}

This section compares the traditional approach used in the United States to finance new highways, with an alternative where a private firm builds and operates the highway, financing all related expenditures with user

\footnotetext{
${ }^{7}$ This contrasts with the early acceptance of this idea. Beginning in the 1790's and the first half of the nineteenth century, more than 2,000 companies, looking for ways to make profits by providing road links between interior agricultural markets and ports, financed, built and operated toll-roads with a combined extension of more than 10,000 miles in 1821 .

${ }^{8}$ There also exist a handful of "developer toll-roads", that is, toll-roads built by a developer to enhance the value of their development as well as generate revenues. Examples of developer roads are Adams Avenue Turnpike (Utah), Emerald Mountain Expressway (Alabama) and Foley Beach Expressway (Alabama).

${ }^{9}$ See "Paying on the Highway to Get Out of First Gear." New York Times, April 28, 2005.

${ }^{10}$ See Tollroadsnews.com. 04.27.05.
} 
tolls. Many potential advantages of the private approach are discussed, our main point being that whether these advantages are realized depends crucially on both the franchise auction and contract.

\subsection{Public or Private Provision of Highways?}

Before comparing private and public provision of highways, it is useful to clarify what is meant by these terms. Under public provision, the highway authority finances and operates the highway. Private firms may participate in the design and building stage and may even be selected in competitive auctions. ${ }^{11}$ But once the facility is built, the highway authority operates and maintains it. Construction costs are paid by taxpayers and even when users pay tolls, these are not directly related to construction costs. In what follows, we refer to this approach as the "traditional approach".

At the opposite extreme of the spectrum of public-private involvement in highway provision, ${ }^{12}$ a concessionaire finances, builds and maintains the facility. ${ }^{13}$ As described in Table 1, there exist a series of alternatives between both extremes of the public-private spectrum.

Many private toll-roads, among them most cases in the United States, have been awarded through negotiations between a firm and the transit authority. There is an alternative, popularized by Demsetz (1968), according to which firms compete for the franchise in a process that seeks to emulate a competitive process. In the words of Chadwick, who originally proposed the idea in 1859, competition for the field substitutes for competition in the field. For example, in the typical private toll-road, a Build-Operate-and-Transfer (BOT) highway project is awarded to the firm that makes a bid that charges the lowest toll to road users. Since there are profits to be made by having tolls that are above (average) costs, bidders will compete away any profits. Consequently, the argument runs, these projects will be run as efficiently as if highways (often a local monopoly) were competitive. ${ }^{14}$ An alternative is to have the highway authority set tolls while interested firms compete by bidding the shortest franchise term.

There are many reasons why the BOT approach may be preferred to the traditional approach, some of them based on economic welfare considerations, others motivated by the many political constraints faced by highway authorities:

1. New taxes are not needed to finance BOT projects. This often is an attractive prospect for a cashstrapped local or state governments, since it allows for infrastructure improvements that would otherwise be infeasible (or would take much longer to attain).

\footnotetext{
11 "[The state highway agency] generally awards the contract to the qualified bidder who offers to complete the road according to the exact specifications at the lowest cost." Congressional Budget Office (1998, p. 37). For alternative contracting techniques, still within the traditional approach, see Congressional Budget Office (1998, pp. 37 and 38).

${ }^{12}$ A more extreme version of private provision—selling off the road to a private firm and regulating its tolls-is considered, and discarded, in Section 3.

${ }^{13}$ Gómez Ibáñez and Meyer (1993) and Roth (1996) review the international experience with transport privatization.

${ }^{14}$ There are many variants on BOT contracts. In one of them (IOT), the private firm improves an existing highway, instead of building it from scratch. In another (DBOT), the private firm also designs the highway.
} 
2. Private firms are usually better managed and more efficient than state-owned companies, so maintenance and operations should be more efficient under BOT. ${ }^{15}$

3. Having the same firm in charge of construction and maintenance provides better incentives to invest in quality during the construction phase (see Tirole, 1997). For example, if a highway is going to be used by heavy vehicles, a private firm that has to maintain as well as build the road will probably choose a stronger, more durable pavement (Congressional Budget Office, 1998, p. 47).

4. Cost-based tolls are easier to justify to the public when highway providers are private. This is particularly relevant for the trucking industry, which typically causes damages to the road which are substantially greater than its marginal contribution in tolls (and other taxes).

5. Distributional considerations suggest that those who benefit from the highway should pay for it, as is the case with BOT but not with the traditional approach where new highways are financed with general funds. Note however that highways often produces externalities not captured by users, who should not bear all costs in this case. For example, the franchised road may reduce congestion in an untolled substitute road, or lead to substantial appreciation of land values.

6. When highways are financed from general funds, there are incentives to lobby for them, independently of their social benefits. When part or all of the cost falls on the beneficiaries, these incentives are muted.

7. If major highway investments are needed - as is the case in a number of states-under the the traditional approach a major increase in the highway department's budget is required in order to finance the increased infrastructure investment. Such an increase may be hard to justify politically. The surge of funds may also decrease the efficiency with which resources are spent.

8. In stark contrast to public provision, the BOT scheme uses the market mechanism instead of central planning to screen projects. This helps prevent building white elephants, as no private firm wants to franchise a road that will make it lose money, where a white elephant is defined as a project whose net (of costs) social value is negative. In the case of projects without negative externalities, a positive private value for a franchise is prima facie evidence of positive net social value. The auction for the franchise provides a market test that may filter socially undesirable projects. Moreover, planners can rely on a market test to tell them where profitable public works need to be built. ${ }^{16}$ This is not so under the traditional approach. For example, a white elephant in the United States is the federally financed stretch of I-99 connecting Wolfsburg and Bald Eagle, Pennsylvania. Known as the Bud

\footnotetext{
${ }^{15}$ Note, however that this advantage can be achieved under the traditional approach if the government contracts out management and maintenance operations.

${ }^{16}$ There are, of course, projects whose social value is positive while their private value is negative. In these cases some form of additional income for the franchise holder is unavoidable if a BOT contract is to be used, and this typically dampens (though not necessarily eliminates) the role of BOT as screening device. For more details see Engel, Fischer and Galetovic (2005).
} 
Shuster highway after the influential local congressman, the road carries less traffic in a year than the Washington, DC, Capital Beltway carries in three days (Winston, 2000).

The above advantages of BOT contracts must be weighed against the distortions that may arise from setting tolls above marginal costs, since in BOT contracts the investment, maintenance and operation of the highway during the franchise period are financed via tolls. Most likely, the result of a competitive auction where the award variable is the toll, will lead to a toll that creates a higher distortion than the marginal cost of public funds. An important exception is the case of highways with high demand and sufficient congestion (many urban roads), where it often is possible to set an efficient toll that causes the same distortion (including congestion externalities) as the marginal cost of public funds.

When congestion is not an issue and budgetary restrictions are absent, the highway authority may choose a BOT-type contract where users do not pay tolls and the government pays the franchise-holder according to the number of road users. These payments are referred to as "shadow tolls". Most advantages of PVR contracts remain valid in this case, and the disadvantage of toll distortions is eliminated as well.

\subsection{Potential Problems With BOT Contracts}

The advantages of BOT contracts cannot be taken for granted. The international (and limited U.S.) experience suggest that shortcomings in the auction design, the franchise contract and the regulatory framework have often led to disappointing outcomes, in some cases even calling into question whether BOT contracts should be preferred to the traditional approach.

The BOT approach poses several challenges for the highway authority. First, the franchise-holder is often awarded a monopoly highway, which needs to be regulated. Second, most highway projects face large commercial and policy risks, which have led firms to press the government for income guarantees or the implicit assurance that they will be bailed out should they face financial distress. ${ }^{17}$ But guarantees are undesirable since they are liabilities for future administrations that are not accounted for in the budget and they make white elephants more likely by reducing the risk that the project will lead to losses for the franchise-holder (Engel, Fischer and Galetovic, 1997b). Third, renegotiations are likely in long term contracts, which encourages firms with lobbying experience to underbid in the expectation of renegotiating later ('lowballing') and consequently make white elephants more likely by reducing the risk that the project will lead to losses for the franchise-holder. ${ }^{18}$ This amounts to privatizing profits while socializing losses, thereby reducing public support for private participation in infrastructure provision. Renegotiations can also favor the government, and may amount to regulatory takings increasing risk to the bidders. Fourth, since

\footnotetext{
${ }^{17}$ A study of J. P. Morgan Securities of 14 urban toll-roads concluded that the projections of revenue and traffic from most of the projects were overly optimistic. The study suggests that this finding may prompt potential lenders and equity investors to require government financial guarantees to reduce the risk of investing. See Muller (1996) for details.

${ }^{18}$ See Guasch (2004) for ample evidence on renegotiations of infrastructure concession contracts in Latin America, Laffont (2005) for a theoretical framework that incorporates renegotiations, and Bajari, Houghton and Tadelis (2005) for estimates of the extra cost that renegotiations impose on users.
} 
highway franchise contracts are inherently incomplete, it is important that they adapt easily to unforeseen circumstances, avoiding hold-up problems as that of Orange County's 91 Express Lanes (see Section 3).

Summing up, private toll-roads contracted via a BOT scheme hold significant promise to improve infrastructure in cash-constrained state and local governments. Yet such a scheme entails many challenges for the highway authority, that have often not been met. Not all BOT contracts are the same, as we argue formally in Section 4. Before doing so, we illustrate the potential shortcomings of private toll-roads by looking at the recent U.S. experience.

\section{US TOLl-RoAds DURing The 1990S ANd PVR AUCTIONS}

Many problems have plagued privatized roads. They stem from the combination of demand uncertainty and front-loaded investments. Even the best traffic forecast models are unreliable, because they do not account correctly for users willingness to pay tolls (drivers have been remarkably reluctant to pay tolls unless they have no other choice of route), and also because unexpected economic downturns lower traffic and hence toll revenue. Because highway last for a long time, the recovery of the large initial investment takes a long time, and investors are willing to ask for less compensation if these risks could be lowered.

As an example, consider the 14-mile Dulles Greenway Highway, The Greenway was designed as a BOT facility that would become the property of the state of Virginia after 42.5 years.

Virginia's General Assembly authorized private development of toll-roads in 1988. A group of investors thought that a toll-road linking Washington's Dulles International Airport and Leesburg, Virginia, would be a promising investment. Their expectations were based on the prospect of residential and commercial growth in the area, which was causing increased congestion on existing arterial roads serving the corridor. The Greenway is a limited access highway, extending from the state-owned Dulles Toll-Road, which carries traffic between Washington's Capital Beltway and Dulles Airport, to Leesburg. To finance the Greenway, investors put up $\$ 40$ million in cash and secured $\$ 310$ million in privately placed taxable debt. Ten institutional investors, among them Cigna Investments and John Hancock Mutual Life Insurance Company, provided \$258 million in long-term fixed-rate notes (due in 2022 and 2026). Three banks (Barclays, NationsBank, and Deutsche Bank) agreed to provide part of the construction funding and \$40 million in revolving credit. Loans were to be repaid with toll revenues. Virginia's State Corporation Commission limited the rate of return on the project to 18 percent-as we shall see shortly, this restriction turned out to be irrelevant.

Investors underestimated how much users disliked paying tolls, and initial revenues were much lower than forecasted. Moreover, investors did not count on the State of Virginia widening the congested Route 7 , which serves the same users. Two independent consulting companies had predicted that when the road opened in 1996, with an average toll of $\$ 1.75$, there would be a daily flow of 35,000 vehicles. In practice, however, the average number of vehicles per day turned out to be only 8,500, one fourth of the initial estimates. After tolls were lowered to $\$ 1.00$, ridership increased to 23,000 , still far below predictions. 
Bonds that were issued to finance the project were renegotiated and investors wrote off their equity. After refinancing, and an extension of the franchise term to 60 years, the project became financially sound.

The opposite situation occurred with the California Orange County 91 express lanes. This began as a ten-mile privately-owned toll section of the congested State Route 91, the Riverside Freeway, running from Anaheim to Riverside in California. ${ }^{19}$ Motorists use the express lanes to get relief from congestion by paying up to almost $\$ 11$ for a round trip. The concessionaire was allowed to raise tolls freely in order to relieve congestion, which lead to several hikes. By early 2000, 33,000 daily trips brought the express lanes to the brink of congestion at peak time and the franchise was a financial success. Yet users were suffering enormous congestion in the freeway, and an expansion became urgent. The problem was that when the contract was signed, cash-strapped Orange County accepted a "non-compete clause" that prevented any expansion in capacity until the year 2035. A protracted negotiation followed.

The examples above show that demand risk (both upside, as in the case of Orange County's express lanes, and downside, as illustrated by the Dulles Greenway) is a characteristic of private toll-roads. Things are made worse by the fact that the standard concession contract lasts a fixed number of years, so a few bad years at the beginning of the franchise may not leave a long enough period to recover the initial investment with normal traffic flows. However, note that there is one interesting feature of the Dulles Greenway example: there was no doubt that the project would eventually be profitable, no matter how slowly demand picked up at first. Yet since the franchise period was predetermined, the contract would end before the concessionaire achieved profitability. If the contract had allowed an extension of the franchise term whenever demand turned out to be sluggish at first (and shortening it if demand was higher than expected), the risk to the franchise holder would have been smaller without affecting expected revenues. This reasoning suggests that flexible-term franchises should be used to solve this problem and motivated our work on Present-Valueof-Revenue (PVR) auctions (Engel, Fischer and Galetovic [1996, 2001], also see Sections 4 and 5).

A PVR auction works as follows: ${ }^{20}$

- The regulator sets a maximum toll.

- The franchise is won by the firm bidding the least present value of toll revenue (hence the acronym of PVR).

- The franchise ends when the present value of toll revenue equals the franchise-holder's bid.

- Toll revenue is discounted at a predetermined rate specified in the contract. The rate should be a good estimate of the loan rate faced by franchise-holders.

\footnotetext{
${ }^{19}$ The toll portion, which is known as the 91 Express Lanes, is in the median of the freeway. It is separated from other traffic by a buffer zone. The 91 Express Lanes project was developed under a program authorized by the California legislature in 1989. The partnership raised \$126 million in financing from several sources, including \$65 million in variable-rate loans from Citibank and two French banks and $\$ 35$ million in a 24 -year loan from Cigna.

${ }^{20}$ Adapting what follows to adjudicating a PVR-like contract via bilateral negotiations, instead of using an auction, is straightforward.
} 
The contract can be auctioned with a standard Demsetz auction, the only difference being that, instead of bidding on price, firms compete on the present value of toll revenue they would like to obtain from the project. To our knowledge, the UK was the first country to use a contract similar to PVR. Both the Queen Elizabeth II bridge on the Thames River ( $£ 180 \mathrm{MM}$, operational 1991) and the Second Severn bridges on the Severn estuary ( $£ 331 \mathrm{MM}$, operational 1996) were franchised for a variable term. These franchises will last until toll collections pay off the debt issued to finance the bridges and are predicted to do so several years before the maximum franchise period. The only difference with our PVR proposal is that there was no formal auction. Chile was the first country to use a PVR auction. In February of 1998, a significant improvement of the highway joining the capital, Santiago, and the seaport of Valparaíso ( $\$ 400 \mathrm{MM})$ was assigned in a PVR auction.

Clearly, a PVR contract reduces risk and therefore toll revenue needed to finance the road: when demand is less than expected, the franchise period is longer, while the period is shorter if demand is unexpectedly high. Assuming that the project is sufficiently good that repayment eventually occurs, all demand side risks have been eliminated.

A good franchise design should also make it easy to change the terms of the contract when doing so is socially desirable. Consider again California's 91 Express Lanes. As traffic increased faster than expected, Caltrans (California Department of Transportation) wanted to widen the Freeway in order to accommodate the increased traffic, but was hampered by the non-compete clause in the contract it signed with the owner of the 91 Express Lanes. The clause prevented Orange County from raising capacity at Riverside Freeway without the franchise holder's consent. Given the experience of the Dulles Greenway, this veto power may have seemed reasonable at the time the contract was signed. Nevertheless the situation became increasingly troublesome for the Orange County Transportation Authority (OCTA), which was empowered to negotiate the purchase of the tollway. Unfortunately, the value of the tollway was controversial since, strictly speaking, it should be the present value of profits from the 91 Express Lanes if the franchise continued as originally planned. Even though the lanes cost \$130MM to build, initially the company's value was set at \$274MM in a controversial (and ultimately unsuccessful) attempt at a buyout by a non-profit associated to Orange County. Years of negotiations followed, with frustrated commuters of the 91 Freeway stuck in traffic in the meantime. Finally the express lanes were bought by a government agency for \$207 MM.

If the 91 Express Lanes had been a PVR franchise, finding a fair price at which to buy back the project would have been straightforward, since there is an obvious candidate for a fair buyout value under PVR: take whatever income (in present value) the project has generated so far, compare it to the present value of toll revenue the franchise holder asked for initially and pay the difference (minus expected maintenance and operation costs) to the owner of the franchise. Since this is what the franchise holder would have obtained if the franchise had run its course, she has nothing to complain. It is not unfair for the transportation authority either, since users would have paid this amount in any case. Hence, the contract can include an option to buy out the franchise at that price without frightening off potential bidders in the auction. This solves the 
problem of widening a highway in response to increased congestion, since after buying back the franchise, the Transit Authority can set up another PVR auction with the new, wider specification. As a numerical example, assume that the owners of 91 Express Lanes had asked for \$160MM in present value terms, a fair return on the $\$ 130 \mathrm{MM}$ investment. Suppose they had already collected $\$ 65 \mathrm{MM}$. Then, according to the PVR scheme (and ignoring maintenance and operational costs), OCTA could have bought them out for \$95MM, which is exactly what the owners would have obtained if the franchise had run to term. That is, non-compete clauses become unnecessary under PVR contracts.

While PVR schemes have a big advantage in terms of reduced risk and flexibility (and other characteristics we consider in Section 5), the downside is that the franchise holder has fewer incentives to increase demand for the highway. The reason is that any action that increases demand will shorten the term of the franchise. This suggests that PVR franchises are applicable only for infrastructure projects where service quality is easy to define and monitor by independent parties, such as bridges, tunnels, water reservoirs and roads. On the other hand, PVR is inappropriate for seaports, airports, and public utilities, where service quality is difficult to define and monitor.

The next section formalizes many of the intuitions discussed in this section.

\section{Formal ReSUlts ${ }^{21}$}

The previous section points out a number of potential pitfalls that can be encountered with private tollroads. This raises two questions. First, is it really always the case that private provision of highways should be preferred over the traditional approach? Second, when private provision is desirable, what is the optimal contract design? In this section we provide a normative framework to address both questions.

\subsection{The planner's problem}

For simplicity assume that demand for the road is constant and completely inelastic. Demand may be high $\left(Q_{H}\right)$, with probability $\pi_{H}$ or low $\left(Q_{L}\right)$, with probability $\pi_{L}$, where $\pi_{L}=1-\pi_{H}$ and $Q_{H}>Q_{L}$. The cost of building the highway is the same for all firms and equal to $I$. There are no maintenance or operation costs and the toll is equal to $P$, which is constant across demand states given our assumption of completely inelastic demand.

There are two reasons why ignoring maintenance and operations costs is not a serious limitation. First, these costs are usually smaller than the cost of building the highway. Second, and more important, if maintenance and operations are proportional to road usage, which often is a good approximation, then our framework extends trivially to the case with maintenance and operations costs, as follows: The regulator estimates per-user maintenance and firms bid on the PVR of toll revenue, net of maintenance costs. Since

\footnotetext{
${ }^{21}$ This section follows Engel, Fischer and Galetovic (2003).
} 
maintenance costs are proportional to road usage, the only residual source of risk will be errors in the estimates of maintenance costs and operational costs, both of which are minor.

After the franchise ends, toll revenue goes to the government. All firms are identical, risk-averse expected utility maximizers, with preferences represented by the strictly concave utility function $u(\cdot){ }^{22}$

We begin with the problem solved by a planner who knows $I$. Denote the present value of toll revenue received by the franchise-holder with high demand by $\mathrm{PVR}_{H}$ and with low demand by $\mathrm{PVR}_{L}$. Then

$$
\mathrm{PVR}_{i} \equiv \int_{0}^{T_{i}} P Q_{i} e^{-r t} d t=\frac{P Q_{i}\left(1-e^{-r T_{i}}\right)}{r}, \quad i=H, L
$$

where $r$ is the discount rate, common across firms and the planner, and $T_{H}$ and $T_{L}$ denote the length of the franchise when demand is, respectively, high or low.

The maximization problem assumes that the planner wants to transfer the fewest resources to the project. ${ }^{23}$ It also assumes that the planner can collect toll revenues after the franchise ends, using this revenue to reduce taxes that generate distortions $\lambda_{\tau}>1$ per dollar in the rest of the economy. Since private participation is voluntary, the planner solves the following problem:

$$
\begin{aligned}
\min _{\left\{T_{H}, T_{L}\right\}} & \sum_{i=H, L} \pi_{i}\left[\mathrm{PVR}_{i}-\left(\lambda_{\tau}-1\right)\left(\frac{P Q_{i}}{r}-\mathrm{PVR}_{i}\right)\right] \\
\text { s.t. } & \sum_{i=H, L} \pi_{i} u_{i}\left(\mathrm{PVR}_{i}-I\right)=u(0),
\end{aligned}
$$

where $u(0)$ is the level of utility attained by a firm not undertaking the project.

It is easy to see that $\mathrm{PVR}_{L}=\mathrm{PVR}_{H}=I$ solves the planner's problem. Since the franchise-holder is risk-averse, it is efficient to insure her completely. To do so the planner fixes any toll that ensures that the franchise-holder loses no money when demand is low (that is $P \geq r I / Q_{L}$ ). Since $Q_{H}>Q_{L}$, it follows from (1) that the planner chooses $T_{H}<T_{L}$, so that the term of the franchise is shorter when demand is high. Note that users pay the same amount in both states of nature and thus face no risk. ${ }^{24}$

Would these results change had we modeled congestion, assumed an elastic demand and set optimal tolls? In Engel et al. (2001) we analyze a more general model and study the optimal contract between a risk averse franchise holder and a risk neutral regulator who sets optimal tolls. We show that the optimal contract trades off the distortions caused by tolls against the revenue uncertainty faced by the risk-averse franchise holder. Essentially, this problem is an extension of the standard Ramsey-pricing problem where the length of the franchise is an additional choice variable and distortions are minimized subject to the franchise holder's self-financing constraint. We also show that the optimal contract can always be implemented with exactly

\footnotetext{
${ }^{22}$ This should be interpreted as a reduced form for an agency problem that prevents the franchise-holder from diversifying risk. See Appendix D in the NBER working paper version of Engel et al. (2001) for a model along these lines.

${ }^{23}$ A more general objective function results when demand is not infinitely inelastic, see Engel et al. (2001).

${ }^{24}$ It should be noted that uncertainty in $I$, which may be important in some projects, cannot be eliminated with a variable term contract.
} 
the same optimal auction we describe next.

\subsection{The optimal auction}

Consider first the standard auction mechanism where the government sets a fixed franchise term, and firms bid tolls. Under competitive conditions, the winning bid $P$ satisfies:

$$
\sum_{i=H, L} \pi_{i} u\left(\frac{P Q_{i}\left(1-e^{-r T}\right)-I}{r}\right)=u(0),
$$

which means that $P Q_{H}\left(1-e^{-r T}\right)>I>P Q_{L}\left(1-e^{-r T}\right)$. Hence the winning bid does not reproduce the planner's solution, since the winning bidder is required to face risk.

An alternative auction mechanism is to have bidders compete on the present value of toll revenue they require to finance the highway. In this case the winning firm bids PVR such that

$$
\pi_{L} u(\mathrm{PVR}-I)+\pi_{H} u(\mathrm{PVR}-I)=u(0),
$$

so that the winning bid satisfies PVR $=I$. It follows that a PVR auction implements the social optimum derived in the preceding subsection. Furthermore, the planner can implement the optimal contract using a PVR auction even if she does not know the values of $I$, the $\pi_{i}$ 's or the $Q_{i}$ 's, $i=L, H$. All the planner needs to know is a lower bound for $r I / Q_{L}$ to set a toll that allows the franchise holder to obtain revenue equal to $I$ in the low demand state.

\subsection{Subsidies and the cost-of-funds argument}

It is often claimed that highway franchising is desirable because private firms have access to funds at lower cost. By contrast, governments must resort to distortionary taxation to finance highways. Is this argument enough to make the case for highway franchising? We now relax the self-financing constraint and allow for transfers from the planner to the franchise-holder. In this way we extend the model to allow for traditional contracts, where governments finance roads, as well as BOT contracts.

Assume that the government subsidizes the project in amounts $S_{H}, S_{L} \geq 0$ depending on the state of demand. Then (2) extends to:

$$
\begin{aligned}
\min _{\left\{T_{H}, T_{L}, S_{H}, S_{L}\right\}} & \sum_{i=H, L} \pi_{i}\left[\left(\mathrm{PVR}_{i}+\lambda_{\tau} S_{i}\right)-\left(\lambda_{\tau}-1\right)\left(\frac{P Q_{i}}{r}-\mathrm{PVR}_{i}\right)\right] \\
\text { s.t. } & \sum_{i=H, L} \pi_{i} u_{i}\left(\mathrm{PVR}_{i}+S_{i}-I\right)=u(0) .
\end{aligned}
$$

It can easily be shown that any combination of $T_{H}, T_{L}, S_{H}$ and $S_{L}$ such that the franchise-holder's income in both states is equal to $I$, that is, $\mathrm{PVR}_{i}+S_{i}=I, i=H, L$, solves this problem. Thus, on one hand the 
planner's optimum can be attained with no subsidies at all, by setting $\mathrm{PVR}_{i}=I$ and $S_{i}=0, i=H, L$. On the other hand, the road can be financed only with subsidies, setting $S_{i}=I$ and $\mathrm{PVR}_{i}=0, i=H, L$. The former solution can be attained via a PVR auction, while the latter corresponds to the traditional approach. This multiplicity of possible subsidy-toll combinations indicates that distortionary taxation $\left(\lambda_{\tau}>1\right)$ is not sufficient to make BOT contracts preferable.

The standard line of reasoning points out that subsidies are a more expensive means of financing roads, because they are paid from distortionary taxes. This argument suggests that the franchise-holder should use subsidies (and the ensuing distortions needed to finance them) only when strictly necessary. But this ignores an essential aspect of highway franchising, namely that the highways may also be used to collect public funds, which can be used to reduce distortionary taxes elsewhere. Hence, under the assumptions we made above, one additional dollar of government subsidy generates one additional dollar of toll revenue for the government. This becomes apparent if we rewrite the objective function (3) as:

$$
\sum_{i=H, L} \pi_{i} \lambda_{\tau}\left(\mathrm{PVR}_{i}+S_{i}\right)
$$

where we have ignored a term that does not depend on the planner's choice variables. It then follows that the problem at hand is analogous to the one faced in the case without government transfers, with $\mathrm{PVR}_{i}+S_{i}$ in the role of $\mathrm{PVR}_{i}$. It can also be seen that social welfare depends on total transfers to the franchise-holder, no matter whether these come in the form of a subsidy or toll revenue.

\subsection{When is franchising desirable?}

We have shown that the cost-of-funds argument is not sufficient to justify franchises in our model. But we have not modeled other alleged advantages of BOT contracts. One of the main arguments in favor of franchises is that governments are unable to induce the public works authority to spend efficiently, perhaps because of political economy considerations or outright corruption. This argument can be captured, in an admittedly simplified manner, by letting the cost of subsidies differ from the tax distortions the planner avoids by collecting toll revenue.

Thus, we let $\zeta_{m}$ be the number of dollars needed by the highway authority to give one dollar of subsidies to the franchise holder. This leads to the following planner's problem:

$$
\begin{aligned}
\min _{\left\{T_{H}, T_{L}, S_{H}, S_{L}\right\}} & \sum_{i=H, L} \pi_{i}\left[\left(\mathrm{PVR}_{i}+\zeta_{m} \lambda_{\tau} S_{i}\right)-\left(\lambda_{\tau}-1\right)\left(\frac{P Q_{i}}{r}-\mathrm{PVR}_{i}\right)\right] \\
\text { s.t. } & \sum_{i=H, L} \pi_{i} u_{i}\left(\mathrm{PVR}_{i}+S_{i}-I\right)=u(0) .
\end{aligned}
$$

Note that $\lambda_{\tau}$ is multiplied by $\zeta_{m}$ in the planner's objective function, but not in the franchise holder's participation constraint. This is because the planner needs $\zeta_{m}$ dollars to increase the receipts of the franchise 
holder by one dollar and $\zeta_{m}$ dollars cost $\zeta_{m} \lambda_{\tau}$. In Engel, Fischer and Galetovic (2003) we show that the solution to this problem depends on whether $\zeta_{m}$ is larger, equal or smaller than 1:

- If $\zeta_{m}>1$, the optimal contract involves no government subsidies and the same present value of toll revenue, $I$, for the franchise holder in all states of demand. This contract can be implemented with a PVR auction.

- If $\zeta_{m}=1$, which is the case considered earlier in this section, the planner's optimum can be implemented via any combination of $T_{i}$ and $S_{i}, i=H, L$, such that $\mathrm{PVR}_{i}+S_{i}=I, i=H, L$. This includes, in particular, the BOT contract associated with a PVR auction, and the traditional approach to highway financing, where the road is financed with general funds.

- Finally, if $\zeta_{m}<1$, the optimal contract is such that all income received by the franchise-holder comes from subsidies. Direct government financing is to be preferred to a BOT contract in this case.

What is the intuition behind this result? When the highway authority reduces the subsidy to the franchise holder by one dollar, it relaxes the government's intertemporal budget constraint by $\zeta_{m}$ dollars, which saves $\zeta_{m} \lambda_{\tau}$. But, on the other hand, the franchise holder must appropriate one additional dollar of toll revenue in present value to meet her budget constraint. This forces the government to increase the tax burden by one dollar, which costs $\lambda_{\tau}$. Hence, it will pay to privatize the highway to avoid subsidies if $\zeta_{m}>1$. On the contrary, the traditional method is better if $\zeta_{m}<1$, for then subsidies through the highway authority are cheaper.

It follows from this result that there is a close connection between the desirability of franchising highways and the self-financing constraint: when $\zeta_{m}>1$ the planner prefers to avoid transferring money to the franchise holder, and this imposes the self-financing constraint. A corollary is that guarantees, which are transfers contingent on traffic being low, are undesirable whenever privatization is optimal. Furthermore, profit sharing arrangements are never optimal even if we ignore their negative effect on incentives.

Our result raises the question of whether one of the three parameter configurations considered above $\left(\zeta_{m}>1, \zeta_{m}=1\right.$ or $\left.\zeta_{m}<1\right)$ is more likely to prevail in practice. We argue next that the most relevant case is $\zeta_{m}>1$. Indeed, $\lambda_{\tau}$ in (4) captures the distortions associated with distortionary taxation. $\zeta_{m}$ also includes any source of additional inefficiency associated with the highway agency's management of resources which are added to the inefficiencies caused by distortionary taxation. Even the slightest inefficiency leads to the conclusion that $\zeta_{m}>1$. It then follows that highway privatization indeed should be preferred over the traditional approach because the highway authority manages less money with a BOT approach. ${ }^{25}$

\footnotetext{
${ }^{25}$ Of course, our model does not consider elements that may point in the opposite direction, such as the fact that under BOT contracts there is more opportunity for opportunistic behavior than under the traditional approach, since the relation between the government and private firms covers a much longer time period. Moreover, we have assumed that the cost of building the project under the traditional approach and with a BOT contract are the same. If the public sector has an intrinsic cost advantage so that $\zeta_{m}<1$, then the traditional approach is preferable.. Also, as mentioned above, public provision may be superior if property rights are not sufficiently protected.
} 
To conclude we should mention that $\zeta_{m}>1$ is not an argument against subsidies that correct discrepancies between the social and private value of a highway. The reason is that our exercise is valid when toll revenue can substitute for subsidies. By contrast, almost by definition a discrepancy between the social and private value of a project implies that the franchise holder cannot capture the excess by a direct charge on users-hence one cannot substitute tolls for subsidies. In those cases a standard subsidy, large enough to make the project privately attractive, is warranted.

\section{Designing Highway Franchise Contracts}

The preceding section provided a normative framework to analyze optimal private toll-roads. Our analysis left out a number of relevant issues which we address, less formally, in this section.

\subsection{Franchises and Monopoly Power}

One of the reasons for adjudicating highway concessions in competitive auctions is to dissipate monopoly rents that would accrue to the franchise-holder if she could set tolls at her discretion. As mentioned in the Introduction, the idea is that competition for the franchise will dissipate economic rents and transfer them to users.

Given the limitations faced by traditional regulation, periodic auctions should be more effective in rent extraction than outright privatization of the highway. The problem with this argument is that a franchise establishes a long-term relationship between the franchise-holder and the regulator. They are subject to Williamson's (1985) "fundamental transformation", from an initial competitive auction into a long term bilateral monopoly between the regulator and the franchise-holder, since assets are sunk and it can be very costly for the government to switch supplier or for the firm to avoid being expropriated.

Thus, the bidding mechanism must be designed so as to reduce the likelihood of opportunistic renegotiations. Attention must be paid both to avoiding regulatory capture by the franchise-holder and to the possibility of creeping expropriation by the highway authority (for example, by fixing low tolls after investments have been made).

While the auction of the franchise dissipates rents, some regulation, including the possibility of periodic re-auctioning, is inevitable. First, whenever the franchise enjoys monopoly power, the franchise-holder has no incentives to provide good service quality. Second, since the franchise has a finite time horizon, current franchise-holders do not have the appropriate incentives to invest in maintenance, specially towards the end of the franchise period. The enforcement of quality standards requires the regulator to resist lobbying for leniency by the franchise-holder. If objective quality standards can be defined, as is the case for highways, enforcement may be subcontracted to specialized private firms. This raises the problem of providing adequate incentives for these firms and these incentives depend on the value of a reputation for honesty for inspection firms. 


\subsection{Flexibility Without Fostering Opportunistic Behavior}

As mentioned in the Introduction, franchise contracts tend to be inflexible. This reflects the desire to reduce the risk of regulatory takings or, alternatively, to reduce the power of corrupt regulators to favor franchise owners at the expense of the public. However, there are circumstances when inflexibility may be very costly to society. In particular, it would be useful to have a franchise contract which included a fair compensation for breach of the original contract. Consider, as in the case of the Orange County Express Lane, where demand grew faster than expected and it is desirable to build an additional lane before the franchise term concludes. How should the expansion costs be divided between the franchise-holder, the government and users? How much of the additional income from user tolls is to be appropriated by the franchise-holder?

In such cases, two options are open to the planner. One is to renegotiate the original contract, with the associated problems of bargaining in a bilateral monopoly situation. The second option is to cancel the concession and pay a fair compensation for the profits foregone by the franchise-holder. The problem with the second option is that the fair compensation is the expected present value of future profits had the franchise continued under the original terms. This value depends on future realizations of demand and cannot be inferred from historical data. This value is therefore highly subjective, and having both parties agree on it may lead to endless disputes.

The issue of flexibility also arises when setting tolls. In the case of a fixed term franchise, to reduce risk it is advisable to specify the toll schedule (in real terms) before the franchise begins. Yet this often leads to tolls that are ex post inefficient. For example, in the case of an urban highway which is franchised for 20 years, the high demand uncertainty discussed earlier implies that tolls set in advance will almost surely lead to either inefficiently high levels of congestion, or to politically untenable levels of under-utilization.

PVR franchises are more amenable to changes in tolls in response to changes in demand than their fixed term counterparts, since tolls may vary substantially without affecting the franchise-holder's present value of toll income. Of course, profits are affected, since the franchise term determines maintenance and operational costs, but these costs are usually much smaller than construction costs.

In the urban highway example, a PVR contract could stipulate that tolls will be reset by an independent agency/commission every year in response to demand conditions, so that users internalize congestion costs. Discretion in toll setting would be limited by setting a floor (in real terms) on possible tolls, to ensure that the franchise-holder eventually collects the amount stipulated in the winning bid.

Underlying this intuition is the fact that a PVR franchise is an incomplete contract in which one of the parties (the franchise-holder) has little to fear if the other party (the highway authority) is given full ex post control (in the Grossman-Hart-Moore sense). The government can react to unforseen circumstances in a variety of ways without affecting the franchise-holder's profits, since the franchise-holder cares only about recovering the up-front investment.

A major problem with highway concessions throughout the world has been that contract renegotiations, at the expense of users and taxpayers, have bee pervasive. For example, in the early 1970s France awarded 
four concessions, three of which went bankrupt after the oil shock and were bailed out by the government. Similarly, several of the twelve highway franchises in 70s Spain had higher costs than anticipated, while traffic was much lower than expected, causing three highways to go bankrupt and the renegotiation of the remaining contracts.

It is interesting to note that when the Dulles Greenway ran into financial trouble (set the Introduction), the Virginia legislature considered overturning the 1988 enabling legislation that prohibits state bailouts for such projects. In the end, it rejected a bailout, however, it voted to allow the speed limit of the Greenway to rise (from 55 to 65 miles per hour) in hopes of attracting more motorists (Congressional Budget Office, 1998, p.39) and, more importantly, extended the franchise term by nearly 20 years.

Contractual changes often are not desirable. In some cases, renegotiations allow governments to expropriate concessionaires after they have sunk their investments. In other cases concessionaires renegotiate contracts in order to shift losses to taxpayers. This amounts to a strange form of privatization, where profits accrue to the firm while losses are picked up by taxpayers. Needless to say, if this is allowed, there are no incentives to be efficient and to be cautious in assessing the profitability of the project. Moreover, contract renegotiations favor firms with political connections and ability to renegotiate, to the detriment of efficient competitors lacking political clout. For these reasons, it would be helpful if franchise contracts would reduce the need for renegotiations, since they call into question the purported reasons for privatizing highways.

One of the attractive features of PVR franchises is that renegotiations are less likely than under alternative BOT contracts. Usually contracts are renegotiated by either extending the length of the franchise, increasing tolls or providing a government transfer. Extending the franchise term with an PVR contract is not possible because, by definition, the term is variable. Hiking tolls is ineffective, because it shortens the franchise term without increasing overall income. This leaves government transfers as the only option. And since the franchise holder cannot claim that it will receive less toll revenue than expected, a government transfer is difficult to explain to the public.

\subsection{The Hidden Cost of Government Guarantees ${ }^{26}$}

Since highway franchises have long payback periods and demand is uncertain due to both micro- and macroeconomic uncertainty, firms that are interested in participating in the auction for the project argue that unless the government provides a guarantee of toll revenue, they will be unable to find sources of financing for the project. This taxpayer-financed insurance against risks creates additional problems.

The risks insured against are typically demand risk, construction and maintenance risk, and policy risk. One reason why firms ask for guarantees is that by this means they can unload a large fraction of demand risk. This risk is large, since making accurate demand forecasts, even in a medium term horizon, is extremely difficult. Firms can make fairly accurate estimates of construction and maintenance risks, but policy risk, which includes regulatory takings and the side effects of other government infrastructure decisions is difficult

\footnotetext{
${ }^{26}$ This section follows Engel, Fischer and Galetovic (1997b).
} 
to estimate, except in the short run. Firms are unable to diversify these risks, possibly due to agency problems involving prospective financiers. As argued in the Introduction and formalized in Section 4, it is possible to reduce these risks substantially, thus reducing the need for guarantees, by choosing PVR auction.

Government guarantees can be both explicit and implicit. For example, an explicit demand guarantee that is common in the case of road franchises is a guaranteed minimum assured yearly toll income, which is specified in the franchise contract. This guarantee also serves as partial insurance against policy risk. Another explicit guarantee that is often used is the payment of a preestablished fraction of cost overruns. Implicit guarantees arise due to the possibility of renegotiating the original contract, typically when franchise-holders run into financial trouble.

Explicit government guarantees are undesirable and may offset the benefits of franchising vis-a-vis the traditional approach. First, they reduce firms' incentives to perform efficiently. For example, if the government accepts to bear cost overruns, firms will have little incentives to control them. Or, in the case where the government guarantees a level of toll revenue, they weaken the incentives to screen projects for white elephants, because firms do not bear the costs of investing in bad projects. Second, guarantees shift obligations to future periods and administrations. These contingent liabilities are seldom valued, and they are typically not included in the year-to-year budget or counted as government debt. It is therefore tempting for politicians to give generous guarantees to stimulate investments, collect the political benefits and then pass the bill to future administrations.

Implicit guarantees, which emerge when the franchise contract can be renegotiated ex post, share these undesirable properties, while adding additional problems. They create incentives for firms with good lobbying skills to underbid more efficient firms in the expectation of renegotiating, some time in the future, the terms in their favor. This may prevent the most efficient firm from winning the franchise.

PVR schemes reduce the need for guarantees, since the risk to investors is much smaller. For example, when the Chilean government used PVR to auction the highway joining Santiago, Chile's capital city, with the port of Valparaíso, it did not have to offer guarantees, in contrast to previous highway franchises using traditional fixed-term auctions.

\subsection{Keep the Auction and Franchise Contract Simple}

A desirable property, both of a franchising contract and the corresponding auction design, is that they be simple. A cursory examination of the mechanisms used to auction franchises in different countries shows that this principle is often ignored. ${ }^{27}$

The shortcoming of complex mechanisms is that they depend on many variables, which makes them difficult to analyze and can lead to complaints of evaluator bias. Multifactor point rating systems are commonly used. In order to reduce the scope for evaluator subjectivity, these factors should be quantifiable.

\footnotetext{
27“An ideal transportation finance program balances several objectives. It should raise adequate revenues, encourage efficient use of the system, and be easy to understand and administer." Adams et al. (2001).
} 
However, since the weights assigned to different factors are to some extent arbitrary, they can lead to unanticipated outcomes, thereby increasing uncertainty. Furthermore, complex contracts are not transparent, and this widens both the regulator's and the franchisee's scope for opportunistic behavior. These arguments suggest that the choice of the winner should depend on a single variable.

Highway authorities often choose complex designs in an effort to satisfy the different interests with stakes in the franchise. For example, planner's offering demand guarantees may link them to a profit sharing scheme between the state and the franchise-holder, thereby seeking compensation for the guarantee if the returns exceed a predetermined limit. This makes it difficult for potential bidders to estimate the value of a project and requires sophisticated monitoring.

Another problem with complex contracts is that supervision is more difficult and there may be a lack of coherence between different provisions of the contract, making opportunistic renegotiations more likely. Furthermore, complex contracts hinder the public's ability to understand what has been awarded in the auction, thereby weakening public oversight of the regulator and increasing the likelihood of regulatory capture.

\subsection{Financing BOT Contracts}

PVR franchises should make it easy to float bonds to finance the project, compared with fixed term BOT contracts. It is obvious that for the same toll rate the flow of toll revenue is identical under PVR or a fixed term scheme. The difference is that the franchise term is predetermined in one case and adapts to demand realizations in the other. If demand is low, the franchise holder will be unable to recuperate the investment when the term is fixed, which may lead to default on the bonds. By contrast, under a PVR scheme, the concession extends until toll revenue equals the bid, which rules out default. Of course, under PVR, the bond holders do not know when they will be repaid, but this is less costly than not being paid at all. ${ }^{28}$

The previous argument is easily adapted to public toll-roads. These roads are operated and maintained by the government, and financed via bonds backed by future toll revenue. Due to high demand uncertainty, such bonds are very risky and often defaulted upon. If the date for principal payment of these bonds were flexible, their risk of default could be eliminated. Investors would exchange uncertainty on when they will be paid for uncertainty on whether they will be paid ('default risk'). a high default risk. ${ }^{29}$

\section{6 "Making Projects Attractive for the Private Sector" Often is a Misleading Objective}

It is important to stress that the purpose of competitive auctions is to dissipate rents by transferring them to users. This follows from the more general principle that regulation should ensure firms a normal rate of return. In countries where highway auctions have become common, it is often claimed that "projects must be made attractive for the private sector," which can be interpreted as the idea that one of the goals of

\footnotetext{
${ }^{28}$ For more details, see Engel, Fischer and Galetovic (1997a).

${ }^{29}$ The principal's value would reflect inflation and foregone interest, so that the downside of uncertain repayment would be minor.
} 
privatization should be to transfer rents to private firms. This is clearly wrong. For example, one of the ways of achieving this transfer would be to grant the franchise-holder monopoly power, which runs counter to all known welfare principles. Another would be to grant explicit or implicit guarantees against commercial risks, which, as we discussed earlier in this section, is also undesirable. The main purpose of franchising and privatization is to get socially worthwhile projects done, not to create business opportunities per se or transfer rents to firms.

\section{Conclusion}

An integral solution to current problems in transportation in the United States should consider alternatives to building more highways, such as making public transportation systems more attractive or implementing pricing policies that allocate resources efficiently (e.g., congestion tolls or value pricing). Yet transportation experts have become increasingly frustrated with the inability of government to move in this direction, leading some analysts to suggest that privatization is "the only realistic hope for paring the huge inefficiencies that have developed in urban transportation under public management," thereby shielding it from "entrenched political forces that inhibit constructive change" (Winston, 2000). This rationale provides an alternative motivation to the one presented in the Introduction for studying the economics of private toll-roads and their relevance for the United States, as we done in this paper.

Many of the problems encountered by highway concessions can be explained by the combination of a front loaded investments and substantial uncertainty about demand for the road. In this paper we described a new type of auction that, by taking account of these characteristics, reduces the likelihood of renegotiation. It also promises smaller payments by users, more flexibility to changed conditions and better performance overall.

Private highway franchises represent a valuable idea that can lead to large improvements in infrastructure provision. Nevertheless, the experience accumulated so far shows that there are a number of pitfalls that need to be avoided. Some obvious recommendations are to have firms compete for the franchise contracts, to offer simple business contracts which do not leave important aspects undefined, and to avoid providing income guarantees. More importantly, we suggest a variation to the classic Demsetz auction which awards the franchise to the bidder that asks for the lowest toll. Our proposal is that firms compete on the basis of the toll revenue (in present value terms) requested to build, operate and maintain the road: a PVR auction.

This modified Demsetz auction has a number of advantages: it reduces risk and thus lowers the return required by bidders. It also reduces the need for guarantees and the scope for opportunistic renegotiations. Moreover, the franchise is flexible, because it can incorporate a buyout option that leaves both parties satisfied, so widening the road in response to increased traffic is not an issue. In addition, the tolls can be changed by the Transit Authority in response to changed conditions without harming the franchise holder. PVR auctions solve most of the common problems that occur with highway franchises. In particular, both 
private toll-roads operating in the United States during the 1990s would have avoided the problems they encountered if they had been a PVR franchise. 


\section{References}

[1] Adams, M., R. Hiatt, M.C. Hill, R. Russo, M. Wachs and A. Weinstein, "Financing Transportation in California: Strategies for Change," Institute of Transportation Studies Research Report, University of California at Berkeley, 2001.

[2] Bajari, P., S. Houghton and S. Tadelis, "Bidding for Incomplete Contracts: An Empirical Analysis," working paper, June 2005.

[3] Chadwick, E., "Results of Different Principles of Legislation in Europe," Journal of the Royal Statistical Society Series A22, 381-420, 1859.

[4] Congressional Budget Office Study, "Innovative Financing of Highways: An Analysis of Proposals," Washington, DC: Congress of the United States, 1998.

[5] Demsetz, H., “Why Regulate Utilities," Journal of Law and Economics 11, 55-66, 1968.

[6] Engel, E., R. Fischer and A. Galetovic, "Highway Auctions in Chile," in Spanish, Estudios Públicos 61, 5-37, 1996.

[7] Engel, E., R. Fischer and A. Galetovic, "Reply to Klein and Tirole," in Spanish, Estudios Públicos 67, 215-225, 1997a.

[8] Engel, E., R. Fischer and A. Galetovic, "Infrastructure Franchising and Government Guarantees," in T. Irwin, M. Klein, G. Perry and M. Thobani (eds.) Dealing with Public Risks in Private Infrastructure. Washington DC: The World Bank, 1997b.

[9] Engel, E., R. Fischer and A. Galetovic, "Least Present Value of Revenue Auctions and Highway Franchising," Journal of Political Economy, 109 (5), 993-1020, 2001.

[10] Engel, E., R. Fischer and A. Galetovic, "Privatizing Highways in Latin America: Fixing What Went Wrong," Economia, The Journal of LACEA, 4, 129-158, 2003.

[11] Engel, E., R. Fischer and A. Galetovic, "Highway Franchising with Subsidies," Work in Progress, 2005.

[12] Gómez-Ibáñez, J.A. and J. Meyer, Going Private: The International Experience with Transport Privatization, Washington, D.C.: The Brookings Institution, 1993.

[13] Guasch, J.L. Granting and Renegotiating Infrastructure Concessions, Studies in Development Series. Washington, D.C.: World Bank Institute, 2004.

[14] Muller, R.H., "Examining Tollroad Feasibility Studies," Municipal Market Monitor, J.P.Morgan Securities, Inc., 1996. 
[15] Roth, G., Roads in a Market Economy, Aldershot: Averbury Technical, 1996.

[16] Schrank, D. and T. Lomax, “Annual Mobility Report, Texas Transportation Institute, 2005.

[17] Tirole, J., "Comment on a Proposal for Highway Franchising by Engel, Fischer y Galetovic," Estudios Públicos65, 201-214, 1997.

[18] Williamson, O., The Economic Institutions of Capitalism. New York: The Free Press, 1985.

[19] Winston, C., "Government Failure in Urban Transportation," Fiscal Studies, 21, no. 4, 403-425, 2000. 
Table 1: SpOnsors and FeAtures of Highway FinANCING in the U.S.

\begin{tabular}{|c|c|c|}
\hline Sponsor & Major Features of Financing & Examples \\
\hline Private equity investors & $\begin{array}{l}\text { Finance and develop the project } \\
\text { using private resources }\end{array}$ & $\begin{array}{l}\text { Dulles Greenway (Virginia) } \\
91 \text { Express Lane project (California) }\end{array}$ \\
\hline Private, Nonprofit Entity & $\begin{array}{l}\text { Issues tax-exempt debt backed by } \\
\text { tolls (and without recourse to taxes) } \\
\text { and oversees the project under the } \\
\text { terms of the agreement between the } \\
\text { state and the private developer }\end{array}$ & $\begin{array}{l}\text { TH } 212 \text { (Minnesota) } \\
\text { Southern Connector (South Carolina) } \\
\text { Interstate } 985 \text { (Virginia) } \\
\text { Tacoma Narrows Bridge (Washington) } \\
\text { Arizona toll projects }\end{array}$ \\
\hline Special-Purpose Public Agency & $\begin{array}{l}\text { Issues tax-exempt debt backed by } \\
\text { tolls (and without recourse to taxes) } \\
\text { and oversees the project under the } \\
\text { terms of the agreement with a private } \\
\text { developer }\end{array}$ & $\begin{array}{l}\text { E-470 (Colorado) } \\
\text { Orange County, California, } \\
\text { transportation corridor agencies }\end{array}$ \\
\hline State Agency & $\begin{array}{l}\text { Issues tax-exempt debt backed by } \\
\text { tolls and without recourse to taxes }\end{array}$ & Some turnpikes \\
\hline State Agency & $\begin{array}{l}\text { Issues tax-exempt debt backed by } \\
\text { taxes }\end{array}$ & $\begin{array}{l}\text { Most highway projects that are } \\
\text { financed by debt }\end{array}$ \\
\hline State Agency & $\begin{array}{l}\text { Finances highway on a pay-as-you- } \\
\text { go basis using state taxes and fees } \\
\text { plus federal aid }\end{array}$ & Most highways \\
\hline
\end{tabular}


Figure 1:

SPENDING FOR HIGHWAYS

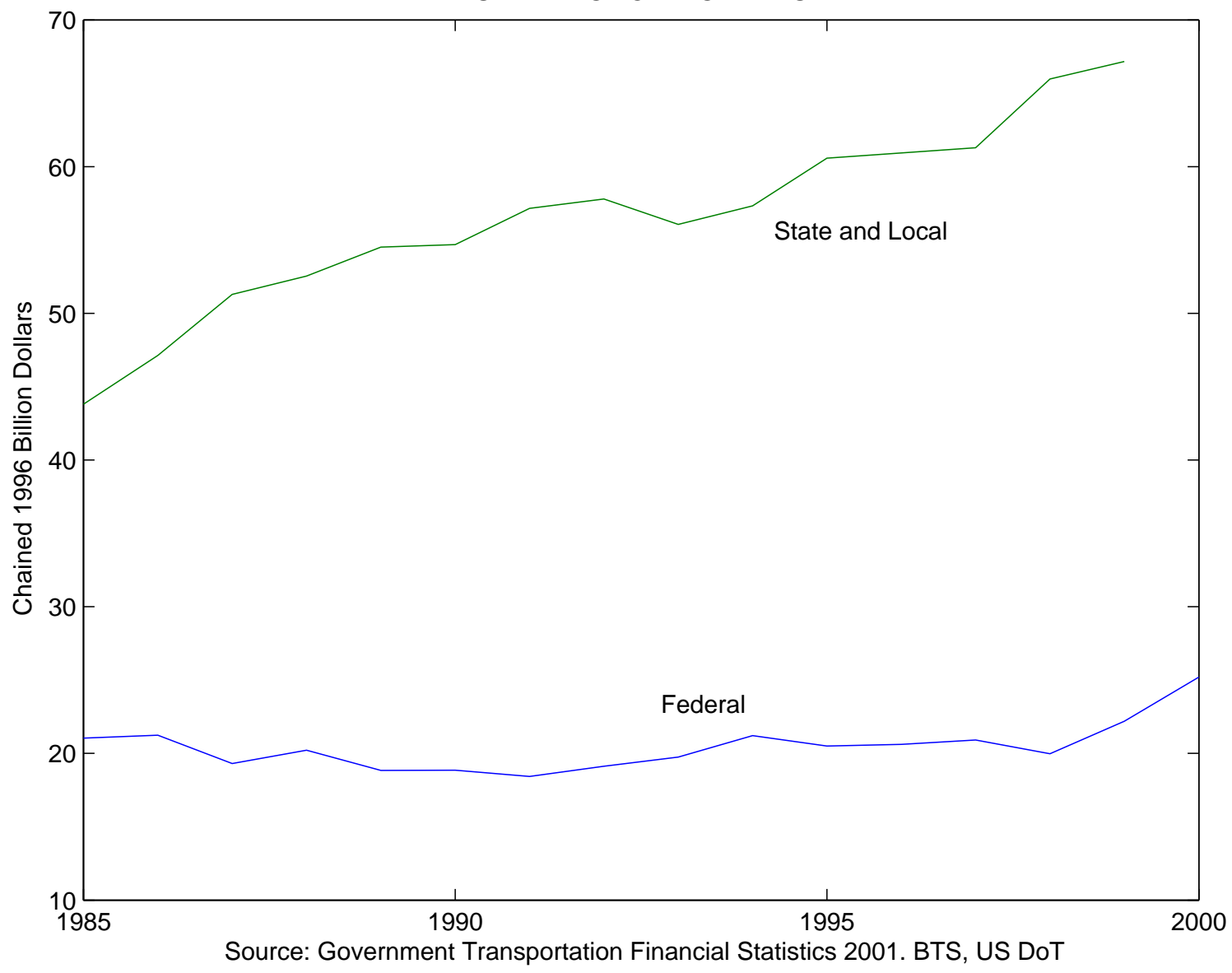


Figure 2:

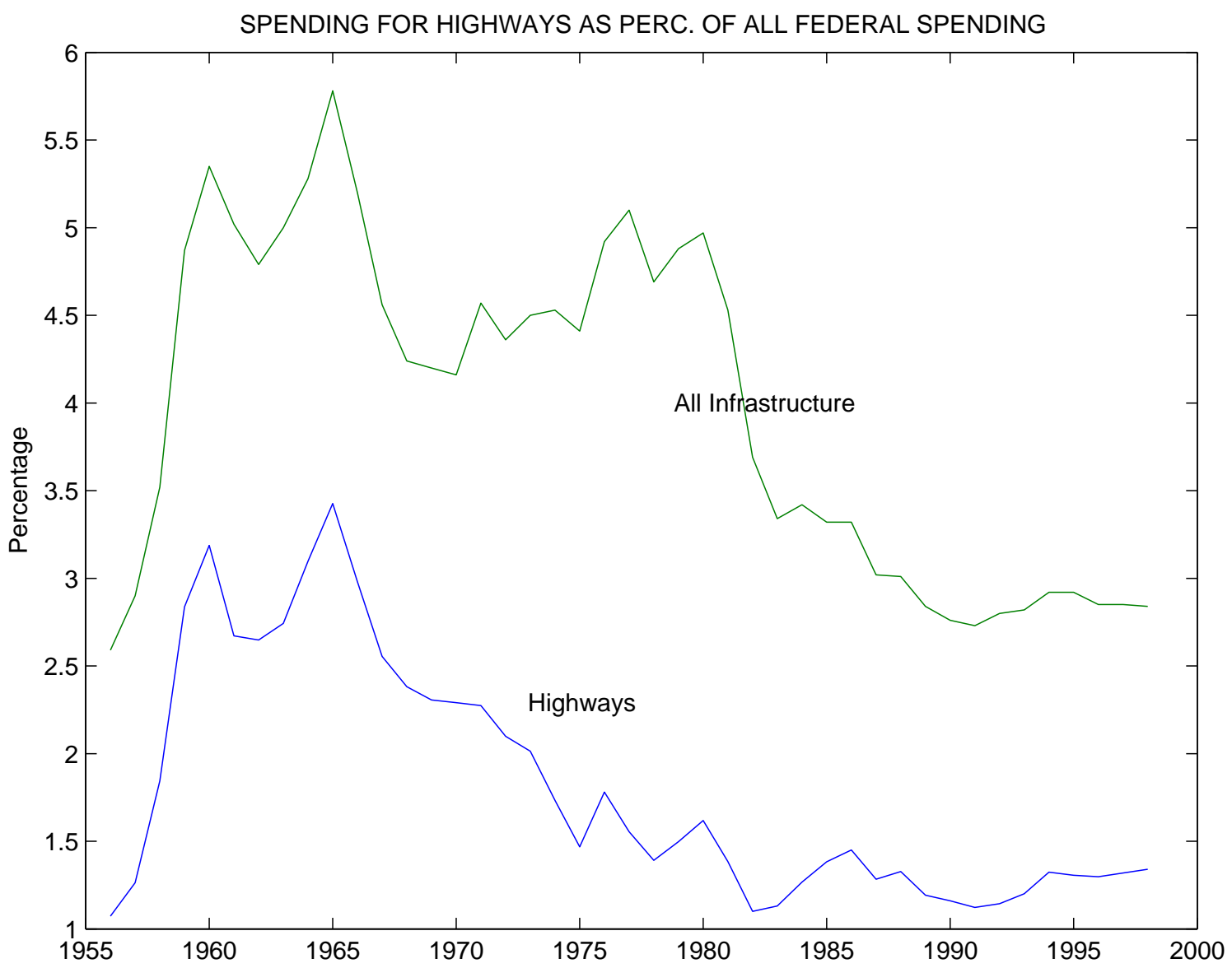

